\title{
Water and Sustainability Issues: A Global Perspective
}

\author{
Sankar $\mathrm{B}^{1}$ and Rajib B ${ }^{2 *}$ \\ ${ }^{1}$ Amguri College, Dibrugarh University, India \\ ${ }^{2}$ Department of Physics, Tezpur University, India
}

*Corresponding author: Rajib Biswas, Department of Physics, Tezpur University, India, Tel: 1-9954313970; Email: rajib@tezu.ernet.in

\section{Mini Review \\ Volume 2 Issue 3}

Received Date: April 30, 2018

Published Date: May 09, 2018

\section{Abstract}

A comprehensive analysis of water resources and global challenges are procedurally investigated. The climate influence on this vital resource is emphasized. It is seen that factual data lead to very grave situation for the human kind. Combining all influential parameters into account, there appears to be an impending danger for future sustainability. An attempt is made to bring all these into notice with plausible measures.

Keyword: Water; Hazards; Resources; Challenges

\section{Introduction}

Water is a resource and the well-acquiesced definition of a resource is its irrenewability. This cognition there by vouches for the fact that the so-often talked about water depletion is a real phenomenon and this irreversibly deplorable process is going on eternally ad infinitum. Here, the sense of depletion is restricted to the nature of potability as there exists an inverse relation between water and potability property. Globally, climatologists agree that sea water level is on a trajectory of crescent (see Figure1) and its tempo of crescendo is though a sign of grievousness [1,2] is still synchronously adumbrating nature's conquest over and superiority to man's known and possessed inventory of tactics and strategies to tackle the contrary phenomenon 'water depletion'(see Figure 2). It is quite evident from Figure 2 how the garve the situation has become $[3,4]$.

A question often stalks our conscience impelling us into a shift of pondering with the genesis of the feeling of our paucity in front of nature's colossality. Let it be accepted that this cognition does not have any geographical limitation-based acceptance but contrarily homo sapiens all over the world voice their accord in the fact that the problem is veritably omnipresent and as such there is justification in throwing light over the aspect of water at the global perspective. In this feature article, an attempt is made to give an ab-initio report on water and challenges that is purvading all over the globe. While doing so, some plausible measures are also suggetsed by taking note of the global scenario.

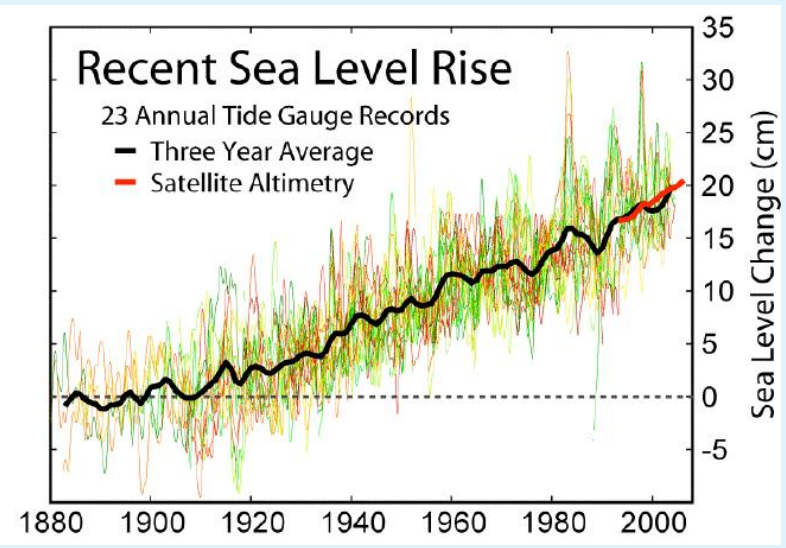

Figure 1: Observed sea level rise. 


\section{International Journal of Oceanography \& Aquaculture}

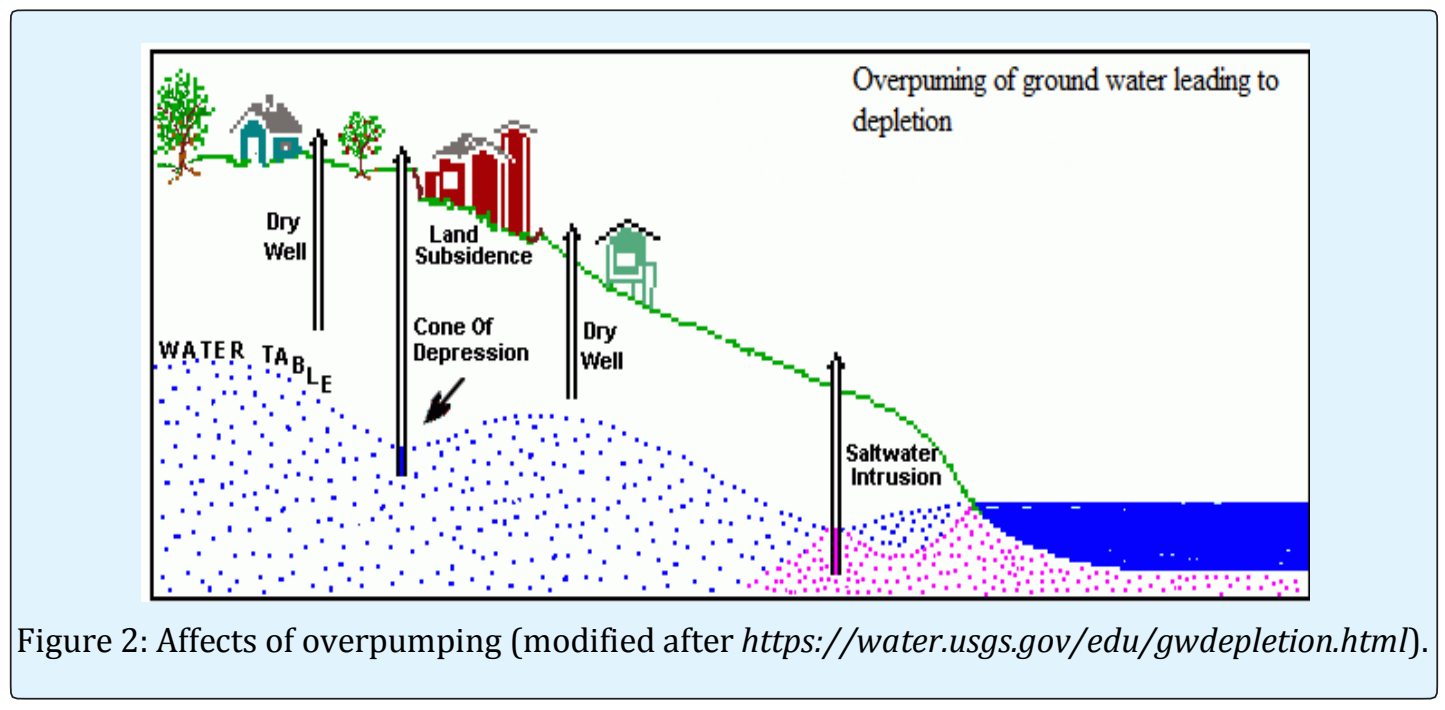

\section{Conducting Globoscopy of Water Scenario}

Scenario of water crisis can be well discussed by making special mention of the North Pole and assessing the prevailing situation there in. North Pole and Magnetic North Pole are more or less synchronous with each other from the spatial point of view. It is well known that the earth keeps tilting at both the poles by a measurement of 23.5 degree. Volcanologists, Seismologists, Glaciologists, Hydrologists well converge in their proposition that the poles have been deplorably impacted by the surge in emission of carbon-based gases. This consequently leads to the entrapment of excessive heat. Thereby, it contributes to the liquefaction of glaciers made out of ice [5-8]. As a result of this, there arises a deconsolidation of the poles [9]. Subsequently, it slows down the rotation speed, auguring the precipitation of intensive earthquakes accompanied by tsunamis possessing enough potential to immerse the earth both in apocalyptic deluge and destruction ad infinitum.

\section{The Curious Case of South-Pole}

Be emphasized that if the case is this in the North Pole, whether there is any case for consolation in the South Pole? Not exactly. The situation prevailing in South Pole is much more terrifying in the South Pole. The biggest glacier McMurdo and the biggest ice shelf Larsen-B are confirmed to have gone through considerable amount of liquefaction [5-7] and to go by Antarcticologis, the phenomenon is irreversible. The transformation of ice into water, though, is a natural phenomenon sounds sinister for the continent. The iceshelfs which cover up the hitherto undiscovered organisms, by being in their primitive form help nourish and sustain the rich variety of the latter. But now the very existence of the latter is being threatened with the conversion of ice into water and the deprivation of the salty water from nutrients, thereby ushering in the advent of destruction for the prevalent flora and fauna. On the one hand, conversion of water into ice is a signification of the fact that commutation mechanics to Antarctica will need a revamp and moreover, the submersion of on-route milestones to Antarctica will considerably disrupt the hitherto simplified circumnavigation mechanics [8]. Actually, there stands more complication. The volatile forties and fifties will be testing the commutation mechanics of man ware and hardware passing through those volatile oceanic belt. Another impending danger is that the dissolved methane in the salty water is getting vents to evaporate into the sky and thereby contributing to the puncturing of the canopy of ozonosphere and through the punctures letting the infiltration of ultraviolet rays and infrared rays and to a great extent the harmful cosmic rays [10-13]. The result is the unimaginable hike in the precipitation of cancer and other viral diseases. Pathologists are of the view that the dismantling of icecaps will facilitate the free movement of viral pathogens. Man will be juggling against the twin attacks of hyperthermia and viral agents and will keep scripting his impending apocalypse. The gist of the prevailing scenario in Antarctica is that we must appreciate the fact that the Antarctic waters should be conserved in their primordial form and that is none other than the ice form.

One thing is veritably factual that until and unless water remains in the form of ice, it will remain a fact of satisfaction and complacence that if water harvesting is mooted, in the light of depletion of ground water levels, then the water deposited in both the poles in the form of ice will come to the rescue. But now that the melting 


\section{International Journal of Oceanography \& Aquaculture}

water is an indication of its inevitable intermixing with the existing water of the polluted seas and oceans, then the idea just discussed will have to be ditched at once [14$16]$.

\section{Oceanic Water}

Oceanic water is another major area of concern in this case. Oceanic water as is well-known is essentially salty as it is fed by the waters transported by the rivers that in turn excavate the geode of mineral nutrients abundantly dotting the riverbeds [14-15]. This being the case, there is no possibility that sea water remains potable. Sea water has two issues with one being extreme salinity and the other being abundance of all forms of pollutants: solid, basically soft and hard plastics; liquid, basically untreated lavatory, industry sewage. Japan has been forever facing the wrath of the sea in the form of tsunamis, typhoons that actually torture the island nation with the deluge of polluted water. The result is that not only beach-adjacent installations get dilapidated but the aesthetics of sea front landscape also great compromised. This dawns a new spate of challenges upon the administration to restore things to normalcy. The point to be understood: is everything not wrought by water. Water here plays the dual role of nurturing life and administering death and destruction. The salinated and contaminated sea water also wreaks havoc in other island nations such as Indonesia, Malaysia, Thailand, Borneo, Australia and New Zealand. Tsunamis and other water-originated natural calamities forever keep on perturbing the tranquillity in the coastal and the maritime areas [16].

Japanese economy is a booming one and as such Japan never underestimates the consolidation of its economy by fully harnessing the available nature-gifted resources [17]. Japan perennially has to confront the water scarcity problem, impacting its rice bowls experiencing water scarcity and also impacting the day-to-day requisition of drinking water. Thus the water that by way of forceful intrusion makes its presence in the entire island nation, gets harnessed quite scientifically. Excess of water gets conserved in the subterranean reservoirs and then is channelized to irrigate the rice bowls. Furthermore contaminated water gets treated in the effluent treatment plants and then is provisioned to cater to the drinking needs [18-20]. The Chinese Territorial Administration of Hong Kong too has been exploiting the sea water to extract out the pollutants and then rationing out the same as per official drinking requisition needs.

Both Japan and China have stood out as role models at a time by exploiting it to serve the noblest causes when another seriously gruesome reality stands in front of us.
In the breast of the pacific ocean, there stands 'Henderson Island' in the south pacific which is said to be most plastic-infested island as all the unwanted plastic junks are jettisoned into the water from the cruises, marine containers, ships, yachts, and whaling boats which finally happen to settle in that island. A question often strikes our conscience, the sea is revered as a manifestation of god in many cultures. But then why is it that the sea which only facilitates transportation, maritime tourism is thus being tormented with loads of plastic and the chemicals there in by mankind. Considering this the oft-used word 'homo sapiens' is a misnomer. Let it be acknowledged that only 'Henderson Island' is not serving as the classic example; but we must have the bearing of this fact in mind that there exist Pacific Garbage Patch, afloat in the Central Pacific and Atlantic Garbage Patch, floating in the Central Atlantic. These Garbage patches often circuitous in nature are matters of worry. The question is the agents who are responsible for the genesis of such phenomena, apparently have no concern for the fact that the world is experiencing depletion of potable water everyday and that sea water filtration is not an easily negotiable exercise. Men turning ignoramuses voluntarily have embarked in scripting the genesis of a third world war to have dominance over water resources in the days to come. Why have they not extracted any sort of lessons from What Japan and Hong kong have engaged themselves in the name of proper exploitation of water resources.

Countries like USA, Canada, China, Brazil, Venezuela and islands such as Costa Brava , Taiwan, Green land and Svalbard need to be studied in relation to water management. USA as we all know is one of the countries known for dumping it industrial wastes into rivers that ultimately merge into both the Pacific and the Atlantic. The states of Florida, Sanfransisco, and Texas are known for having population of shell and oil extraction companies in the maritime areas. Thus it is not unnatural to hear about oil spillage into the sea fore which companies like Shell, Exxon Mobil, British Petroleum have been brought to book. Here two cases of stupidity need to be highlighted. USA being an advanced country, with deeper forays in seismology, aviation, electronics, nanotechnology does not ever consider the necessity of tackling unprecedented calamities arising out of technical disruption? How can then USA be called a $1^{\text {st }}$ World Country?. It has not yet invented any technology to nullify possible oil spillage and thereby preventing water contamination. The answer lies in the fact for the USA , the importance is commercial and technical colonization. Neither Canada, nor the German Government centred in Berlin ever have considered the importance of mooting over the issue of scum or slug channelization into sea 


\section{International Journal of Oceanography \& Aquaculture}

water. Same is the case with China. The beaches of USA, China and Germany play host to beach sculpture festival wherein the issues pertaining to water have been showcased. These countries also host from time to time Environment -based movies highlighting water issues. But the reality is that nothing significant has been positively thought out by these countries. Again if we think of the island of Costa Brava, notorious for carefree etiquette where tourists can surpass all levels of shame, the island has reaped notoriety also for the fact that tourists wastage water beyond imagination.

All the above mentioned realities point to the fact that water wastage is not an easily negotiable issue and the tourism industry is wreaking havoc on it. Especially higher amount of water contamination is reported in those countries the economies of which are extensively fed by tourism. Let the attention be shifted to India as it is going to surpass China soon in world population. As such the danger looms large in India regarding the emergence of a terrifying crisis in the domain of water.

\section{Water Scenario in India}

As commented above, India is a country which has tacitly reaped notoriety for its in ability to arrest the pace of population explosion, there by indicating its possibility of surpassing China in terms of population. The other name for high population is sky-rocketing trend of landscape putrefaction. One of the specimens of this very trend is indubitably the prevalence of large-scale solid and liquid waste dumped into the water bodies. The industries have been regularly dumping their chemical sewage and house holds, offices, temples, all organizations both governmental and non-governmental. By dumping sewage into water, there is being done a sort of wilful sabotaging of the available potable drinking water. But what is more shocking is that more a than required amount of water is harnessed in meeting day-today requisition in the households and even the industrial exploitation of water too is equally shocking. But there is an additional twist to the story too. Contaminated water through its overspill during floods and breakage of sluice gates damage the reservoir of potable drinking water converting the latter into a hotbed of pathogens.

This makes us to think over how the existing scenario of water treatment be reversed. At the household level as mentioned earlier, there is reported ground water depletion (Figure 1). Ground water is receding and the suction of water from the subterranean zones of the earth through the installation of submersibles and jet pumps is not at all cost-effective. Whatever amount and form of water is extracted out from whatever depths of the ground by harnessing costly technology even, this no way guarantees that the water is free from arsenic fluoride, chromium, mercury, arsenic and asbestos. Man is consuming water extracted out of the ground and has fallen victims to diseases such as Lou Gehrig's disease (caused by excessive iron concentration in water), MInamata Disease( caused by mercury concentration), fluorosis. This warrants for the fact that water after having been sucked out from the ground needs to be refiltered and boiled to be made suitable for drinking, Despite having had this knowledge, we should have started optimal using of water. But sorry to say that this practice has not yet set in. Also if we become considerate enough we can think about disposing solid and liquid waste differently and thereby can cut down our dependence on water. Even if it becomes unavoidable that the water from the kitchens, lavatory at the household level gets dumped into community canals. The canals should have a cul de sac. At the terminus, there should be installed treatment plants that will separate water from the slug, will process filtration through modern filtration devices, will ensure the sieving of plastics. Once done plastics can be put to recycle and whatever forms of slug or sediment remains that may be converted into manure if possible. If that is impossible, then there should be facility for smokeless incineration. Thus definitely households can ensure optimal and eco-friendly exploitation of water. If this can be ensured, the water in the riverbeds will remain pristine forever. The already contaminated water of the river also needs to be refiltered through the adoption of the same process. If all households, industries and establishments thus go for the adoption of such kind of strategies, then water pollution phenomenon can be checked to a great extent.

In other words effluent treatment plants at the household level, industry level and also at the governmental level must be considered as needs of the hour. Households should work out minimal use of water and installation of water treatment plant and nondumping of contaminated kitchen or lavatory water into water bodies rather than channelizing them into non-used boreholes. In this connection, a point to be highlighted is that when crude oil and gas companies pipe out the crude oil from the recesses of the earth, often there falls vacuum in the crust of the earth, thereby enhancing possibility of earthquakes and large scale disasters. The amount of contaminated water that gets generated in the house hold can be used as fillers for those kind of holes.

\section{Conclusion}

All over the world, water issues are more or less the same. Whether India, China or USA the same challenges 


\section{International Journal of Oceanography \& Aquaculture}

do confront us. Man must reconsider his attitude to harnessing water. Till date the issues that mankind have faced are well-wrought by his own in considerateness and wilful ignorance. But man has to come out of this moult of passivity. It is imperaive that there is a need of reactivation of constructive thinking which will pave the way to find out the plausible measures. This will eventually lead to effective implementation of policies amongst stake holders to harness the power of this vital resource for betterment of society around the globe.

\section{Acknowledgements}

We express our gratitude to the editor for allowing us the opportunity of jotting down this article.

\section{References}

1. Malciu V (2000) Implications of accelerated Sea-level Rise (ASLR) for Romania. Proceeding of SURVAS Workshop on European Vulnerability and Adaptation to impacts of accelerated Sea-level Rise (ASLR). Hamburg, Germany.

2. Snishko S, Kupriko I (2002) Waterflow of Black Sea basin mean rivers and its variability. $21^{\text {st }}$ Conference of the Danube countries, on the Hydrological forecasting and hydrological bases of water management, Bucharest, Romania.

3. Attwater R, Anderson L, Derry C (2016) Agricultural risk management of a peri-urban water recycling scheme to meet mixed land-use needs. Agricultural Water Management 176: 266-269.

4. Carpenter SR, Stanley EH, Vander Zanden MJ (2011) State of the world's freshwater ecosystems: Physical, chemical, and biological changes. Annual Review of Environment and Resources 36: 75-99.

5. Qiu J (2010) Measuring the meltdown. Nature 468: 141-142.

6. Steffen K, Box JE (2001) Surface climatology of the Greenland ice sheet: Greenland climate network 1995-1999. J Geophys Res 106: 33951-33964.

7. Bamber JL, Alley RB, Joughin I (2007) Rapid response of modern day ice sheets to external forcing. Earth Planetary Science Letters 257: 1-13.

8. Bassett SE, Milne GA, Mitrovica JX, Clark PU (2005) Ice sheet and solid earth influences on far-field sealevel histories. Science 309: 925-928.
9. Dong R Choi (2011) New Concepts in Global Tectonics Newsletter. 61: 1-148.

10. Lomond JS, Tong AZ (2011) Rapid Analysis of Dissolved Methane, Ethylene, Acetylene and Ethane using Partition Coefficients and Headspace-Gas Chromatography. J Chromatogr Sci 49(6): 469-475.

11. Liu Z, Yin H, Dang Z, Liu Y (2014) Dissolved Methane: A Hurdle for Anaerobic Treatment of Municipal Wastewater. Environ Sci Technol 48: 889-890.

12. Cho S, Shin MH, Kim YK, Seo JE, Lee YM, et al. (2009) Effects of Infrared Radiation and Heat on Human Skin Aging in vivo. J Investig Dermatol Symp Proc 14: 1519.

13. Lee P, Weelden HV, Bruijnzeel PB (2009) Neutrophil Infiltration in Normal Human Skin After Exposure to Different Ultraviolet Radiation Sources. Photochem Photobiol 84(6): 1528-1534.

14. Vikas M, Dwarakishb GS (2015) Coastal Pollution: A Review. Aquatic Procedia 4: 381-388.

15. Jose Derraik GB (2002) The pollution of marine environment by plastic debris- a review. Marine Pollution Bulletin 44(9): 842-852.

16. McDermid KJ, McMullen TL (2004) Quantitative analysis of small plastic debris on beaches in the Hawaiian archipelago. Marine Pollution Bulletin 48(78): 790-794.

17. Ogi H, Fukumoto $Y(2000)$ A sorting method for small plastic debris floating on the sea surface and stranded on sandy beaches. Bulletin of the Faculty of Fisheries Science, Hokkaido University 51(2): 71-93.

18. (2008b) FY2007 Result of Environmental Survey on Dioxins (in Japanese) Ministry of the Environment. http://www.env.go.jp/air/report/h20-06/

19. Teuten EL, Saquing JM, Knappe DRU, Barlaz MA, Jonsson S, et al. (2009) Transport and release of chemicals from plastics to the environment and to wildlife. Philosophical Trans actions of the Royal Society B 364 (1526): 2027-2045.

20. Nakanishi Y, Horiguchi F (2006) Tributyltin Risk Assessment Document. Book Series No (8), Maruzen. 